\title{
As possibilidades de implementação da educação a distância (EAD) na educação de jovens e adultos (EJA) no município de Barra Mansa-RJ.
}

Tânia Cristina da Silva

Mestranda em Biologia Animal. ab. de Ensino e Pesquisa em Morfologia de Animais Domésticos e Selvagens. Departamento de Anatomia Animal e Humana. Instituto de Ciências Biológicas e Saúde. Universidade Federal Rural do Rio de janeiro. BR. 465, KM 07, s/ número - Seropédica - RJ - Brasil. 


\section{Resumo}

Esta pesquisa aborda um dos temas mais discutidos na atualidade, a Educação a distância (EAD) com ênfase na Educação de Jovens e Adultos (EJA). Os cursos de EJA/ EAD vêm recebendo estudantes das mais variadas faixas etárias, classes sociais e diversos profissionais. Sua finalidade é a conclusão da educação básica e muitos o procuram em busca de melhores condições de trabalho, almejando o ingresso no ensino superior ou técnico. Mas a evasão é um desafio a ser superado nessa modalidade. Dessa forma, buscamos, nesta pesquisa, a opinião de alunos sobre a realidade. Foram aplicados 112 questionários em três escolas municipais de Barra Mansa, a fim de visualizar, por meio dos resultados, as percepções dos estudantes em relação a oferta da Educação de Jovens e Adultos (EJA) na modalidade a distância. Diante dos resultados apresentados, verificamos que, entre outras questões, essa modalidade de ensino a distância é desconhecida por grande parte dos participantes desta pesquisa.

Palavras-chave: Educação de Jovens e Adultos; Educação a Distância; Evasão

\section{Abstract}

This research addresses one of the most discussed topics nowadays, Distance Education (DE) with emphasis on Youth and Adult Education (YAE). The YAE/DE courses have been receiving students of the most varied age groups; social classes and various professionals. Its purpose is the completion of basic education and many seek it in search of better working conditions, aiming for entry into higher education or technical. But evasion is a challenge to be overcome in this modality. In this way, we seek, in this research, the opinion of students about this reality. 112 questionnaires were applied in three municipal schools in Barra Mansa, in order to visualize through the results, the students' perceptions regarding the offer of Youth and Adult Education (YAE) in the distance learning modality. Given the presented results, we found that, among other issues, this modality of distance learning is unknown by most of the participants of this research.

KEYWORDS: Youth and Adult Education; Distance Education; Evasion 


\section{Introdução}

No contexto, a pesquisa aborda os motivos que levam os estudantes - diante dos desafios enfrentados e que se tornaram um obstáculo na Educação, tanto na modalidade de ensino presencial, a distância e na Educação de Jovens e Adultos- à evasão.

Para obter as informações contidas na pesquisa, foi elaborado um questionário com questões relacionadas a atividades que os alunos inseridos na modalidade de ensino do EJA realizam no cotidiano: se têm vinculo empregatício, se exercem atividades empreendedoras ou afazeres do lar, pois estes parâmetros podem vir a influenciar no aprendizado em função do esgotamento fisíco e psicológico; idade para traçar o perfil dos alunos em relação a faixa etária e comprometimento. Presumi-se que os motivos que fazem o EJA atrair esse público diversificado e direcionado para conquista de uma educação básica (ensino fundamental e médio), concluído, para muitos um sonho, não estão sendo o suficiente, em função de outros fatores que fazem com que os estudantes desanimem de concluí-lo elevando em números a evasão.

Diante dos inúmeros problemas enfrentados na educação, que se constituem como desafios tanto para docentes e discentes, temos na Educação de Jovens e Adultos, o recomeço, o retrato da sociedade brasileira representada por trabalhadores que lutam contra o cansaço em busca do ler, escrever; indivíduos marginalizados que procuram em sala de aula o resgate da cidadania; herdeiros do analfabetismo familiar, e estudantes que vislumbram um futuro melhor através da educação.

Por outro lado, no mesmo cenário nos deparamos com estudantes imaturos, desmotivados, vindo do insucesso do ensino regular e repleto de normas comportamentais que exigem uma postura e aprovação ao final do período. E por compartilharem o mesmo espaço em sala, essas atitudes dificultam a aprendizagem e fazem com que muitos tenham inúmeras idas e vindas do ambiente escolar, sendo a evasão um dos grandes problemas enfrentados na educação. 
E, atrelado a este contexto o docente tenta inovar e agregar conhecimentos peculiares para despertar atenção e atingir o objetivo que é a construção do saber.

$\mathrm{Na}$ esteira desse processo, a educação a distância tem contribuído de forma relevante na educação de um grande público, essencialmente, no ensino superior. $\mathrm{E}$ isso faz com que está modalidade seja alvo de vários estudos na tentativa de se conhecer e expor suas qualidades, sendo de suma importância na formação do cidadão.

Alguns fatores influenciam no processo de ensino-aprendizagem dos alunos inseridos nessa modalidade de ensino, um deles é que o aluno tem que ser autônomo em busca do conhecimento, participativo nas discussões dos fóruns e atividades propostas.

Segundo Silva (2004, apud CARVALHO, 1994), algumas dentre várias vantagens da aprendizagem autônoma é que esta permite ao aluno aprender melhor, por buscar maior aprofundamento nos assuntos de seu interesse; contribui para enriquecer os conhecimentos dos alunos; o aluno aprende a se libertar da dependência do professor e passa a descobrir formas alternativas de construir o conhecimento. Silva (2004,s.p.), destaca que nessa "aprendizagem autônoma pode-se reconhecer três componentes que desempenham importante papel em todo o processo: o componente do saber, o do saber fazer e o do querer".

De acordo com Oliveira (2006), o aluno precisa estar focado em aprender e reaprender sempre, ou seja, quando necessário, reconstruir conceitos diante de novos paradigmas, pois "quando falamos de construção do conhecimento, o fazemos não somente no sentido do conteúdo a ser conhecido, mas também das bases epistemológicas e metodológicas”(p.15). Ressalta que é preciso estar disponível à discussão, questionar sempre quando não entender ou discordar, buscar por mais conhecimento; tem que ser um desafio constante, tendo em vista o somatório de vários aspectos, uma vez que "elementos conscientes e inconscientes incorporam muitas coisas que ajudam a definir as pessoas como indivíduos"(FONTANA, 2002, p. 199).

Assim como na modalidade presencial, ocorre, na modalidade a distância, a evasão, sendo esta considerada um desafio. Faria et al (2008), destaca que a evasão universitária tem se caracterizado como uma realidade recorrente no âmbito do ensino 
de graduação em várias partes do mundo. No caso dos cursos a distância, os índices de evasão são expressivamente maiores do que nos cursos presenciais. Outro resultado importante destacado pelas autoras acima é que o motivo de desistência nos cursos presenciais são fatores socioeconômicos; nos cursos a distância, esses fatores se somam a diversos outros, com igual ou maior importância. Os cursos a distância apresentam diversos aspectos que propiciam flexibilidade aos alunos, mas também possuem desafios a serem superados, como a dificuldade para acompanhar um cronograma de estudos, problemas com a tecnologia necessária para um melhor aproveitamento e a necessidade de autonomia do estudante para coordenar sua aprendizagem. Isso pode levar os alunos a desistir do curso sem concluí-lo.

Almeida (2008), ao analisar os motivos de desistência de um curso de EAD de especialização, classifica em cinco categorias principais os alunos que abandonam o curso. A primeira categoria refere-se aos fatores situacionais que ocorrem durante $o$ curso e que podem levar o aluno à evasão. Entre esses fatores, a autora cita a falta de apoio no trabalho, curso simultâneo, problemas familiares e falecimento de familiares, entre outros. Moorey e Kearsley (2008) destacam que os alunos mais propensos a se sair bem em cursos a distância são aqueles menos influenciados pelo ambiente que os rodeia. Os autores acreditam haver ainda relação entre o sucesso e a introversão-extroversão dos alunos, seu perfil e sua personalidade. A segunda categoria destacada por Almeida (2008) é a falta de apoio acadêmico. Nela estão aqueles alunos que não consideram adequado o apoio acadêmico dado pelo curso.

No entanto, podemos observar que entre as vantagens apontadas para que a EJA se aproprie cada vez mais dos pressupostos da educação a distância, pode-se destacar o fato de que a EAD estaria pronta a responder mais rapidamente às necessidades de formação para o mercado de trabalho.

A escolha do tema deve-se ao fato de a Educação de Jovens e Adultos, entendida como modalidade da educação brasileira que tem como objetivo atender todos os cidadãos que não tiveram acesso à continuidade de estudos no ensino fundamental e médio na idade apropriada, apresentar-se como um dos segmentos da educação para a qual poderá ser ampliada a introdução da educação a distância como possibilidade de oferta de ensino. 
Portanto, a pesquisa contribui com a análise das atuais políticas públicas de Educação de Jovens e Adultos (EJA) e sua implementação no contexto de Educação a Distância (EAD).

Ao se considerar a atualidade do tema, objetivou-se uma necessária investigação que trate de como essas duas modalidades de ensino têm sido abordadas na realidade brasileira e suas possíveis conexões. A ênfase foi direcionada à análise das atuais políticas públicas de Educação de Jovens e Adultos e sua implementação no contexto da educação a distância, investigando as expectativas e percepções dos estudantes da Educação de Jovens e Adultos sobre a oferta do curso na modalidade a distância e os motivos que fazem os estudantes da Educação de Jovens e Adultos optarem pela modalidade da educação a distância. Assim, será possível compreender as razões da baixa frequência na regularidade da Educação de Jovens e Adultos e identificar-se se a modalidade em EAD contribuiria para a diminuição dos índices de evasão.

\section{Metodologia}

O trabalho reveste-se de importância por buscar compreender de que maneira as políticas públicas estão sendo aplicadas na oferta de cursos para Educação de Jovens e Adultos na modalidade a distância. Além disso, a análise de experiências que integrem EAD e EJA permitirá que novos debates sejam travados no sentido de se buscar uma melhoria na oferta de uma educação de qualidade para todos.

Devido a essa característica, trabalhar do amplo (Políticas Pùblicas) para o particular (unidades escolares) e ainda, possibilitar mensurar e interpretar os dados obtidos, a Pesquisa Qualitativa foi o método de pesquisa que permitiu essa abordagem, pois, segundo Souza:

A pesquisa qualitativa responde a questões muito particulares. Ela se ocupa, nas Ciências Sociais, com um nível de realidade que não pode ou não deveria ser quantificado, ou seja, ela trabalha com o universo 
dos significados, dos motivos, das aspirações, das crenças, dos valores e das atitudes. (Souza, apud Minayo, 2013, s.p.).

A pesquisa foi realizada através da técnica de estudo de caso por permitir a contextualização e direcionamento para o objetivo geral: "Analisar as atuais políticas públicas de Educação de Jovens e Adultos e sua implementação no contexto da Educação a Distância”, mais especificamente nas unidades escolares públicas da Região Sul Fluminense no Estado do Rio de Janeiro, ou seja, analisar-se-á um problema amplo, visando uma aplicabilidade particular. De acordo com Saldanha (apud LUDKE, 2003, p.15), esse processo de trabalho científico percorre três etapas: (1) fase exploratória; (2) produção de dados e (3) análise e tratamento do material empírico e documental. Também foi utilizada no presente trabalho a pesquisa bibliográfica ou de fontes secundárias, que segundo Marconi; Lakatos (2010, p.166)

[...] abrange toda bibliografia já tornada pública em relação ao tema de estudo, desde publicações avulsas, boletins, jornais, revistas, livros, pesquisas, monografias, teses, material cartográfico etc $[. .$.$] Sua$ finalidade é colocar o pesquisador em contato direto com tudo o que foi escrito, dito ou filmado sobre determinado assunto, inclusive conferências seguidas de debates que tenham sido transcritos por alguma forma, quer publicadas, quer gravadas.

Esse tipo de pesquisa propicia um exame aprofundado do assunto, podendo-se, a partir da contribuição de vários autores, proceder a um estudo analítico dos textos sob um novo enfoque e, assim, chegar a conclusões inovadoras.

\section{Organização do Trabalho}

A pesquisa iniciou-se com a produção de dados com análise documental: ordenamento jurídico (leis, decretos) e publicações de trabalhos científicos, elaboração e aplicação de entrevistas com os(a) gestores(a) e aplicação de questionário nos alunos matriculados na EJA presencial.

O questionário buscou elaborar um panorama para a pesquisa, procurando delimitar as principais dificuldades, mensurando o que essa modalidade apresenta como 
vantagem ou desvantagem no processo de ensino aprendizagem e percepção que os alunos têm da educação a distância, visando à apreensão da realidade.

As entrevistas foram elaboradas com questões abertas sobre diversos aspectos relacionados a modalidade: visão administrativa, ambiente escolar, grau de autonomia, abrangendo os programas educacionais governamentais e as metodologias aplicadas na EJA, finalizou-se com a abordagem da implementação das modalidades EJA/EAD em cada unidade escolarer e/ou instituição participante.

O trabalho foi desenvolvido em etapas concomitantes, com agendamento prévio; foram entrevistados coordenadores, gestores públicos e privados e realizado o registro para análise dos dados coletados. Alguns roteiros de entrevista foram enviadas por email, devido a impossibilidade de visita aos locais.

A abordagem com os alunos foi realizada nas unidades escolares com a aplicação presencial de questionário, inicialmente em dupla; mas, para alcançar um número significativo, optou-se por trabalho individual, aplicou-se questionários e entrevistas em unidades escolares distintas. O procedimento adotado permitiu conhecer a rotina escolar, estrutura física proporcionada aos discentes, além da metodologia utilizada nos cursos. A estratégia consistia em apresentação à direção e coordenação responsável pelo turno nas unidades escolares, com solicitação de realização da entrevista e de visita às dependências da escola.

$\mathrm{Na}$ fase de análise dos dados, foi compilado o percentual de repostas às questões, com detalhamentos dos dados referentes às perguntas. $\mathrm{O}$ resultado de todo esse processo investigativo são apresentados nas proposições finais desse trabalho.

Sendo assim, no primeiro momento, serão verificadas as políticas públicas direcionadas para as duas modalidades de ensino, buscando-se analisar o contexto histórico em que foram produzidas e sua aplicabilidade no contexto atual.

Este trabalho buscará, também, desvelar os pontos críticos e de sucesso nas propostas de Educação de Jovens e Adultos na modalidade a Distância já implementadas e quais os pressupostos teórico-metodológicos que embasam as propostas desses cursos. Para tanto, buscar-se-á analisar experiências de cursos a distância no âmbito público e privado que já utilizam o ensino a distância integrado com 
a EJA e verificar, também, qual a percepção dos discentes em relação à introdução da modalidade de ensino a distância na Educação de Jovens e Adultos. Pretende-se apreender tal perspectiva por meio de questionamentos aos alunos que estão matriculados em cursos de Educação de jovens e Adultos (EJA) presenciais.

Tendo em vista o objetivo desta pesquisa, o trabalho foi dividido em três capítulos: Introdução, Pressuposos Teóricos, Expectativas e percepções - discentes e gestores e conclusões.

\section{Fundamentação Teórica}

A importância da educação na sociedade moderna tem sido enaltecida por segmentos diversos como solução para as dificuldades econômicas e sociais do mundo , a universalização e democratização do ensino é fundamental nessa trajetória, nesse sentido, o processo de transformações tecnológicas pode auxiliar a inclusão educacional ou aumentar as desigualdades sociais (DE LIMA, 2010, s. p.).

No Brasil, os desafios a serem superados são grandes, considerando a proporção territorial, as diferenças regionais e a atual estrutura educacional vigente no país. De fato, países desenvolvidos utilizaram o sistema de ensino como suporte para as pesquisas científicas e áreas humanas, direcionando-o para as necessidades do setor produtivo, suprindo o mercado com mão de obra qualificada e preparada para as exigências nacionais.

A Lei de Diretrizes e Bases da Educação Nacional (1996) estabeleceu que o acesso à educação básica obrigatória é direito público subjetivo, contemplando todos os níveis e modalidade de ensino, conforme competência legal determinada na Constituição Federal (1988), devendo a União atuar de forma supletiva em todos os segmentos, sendo livre a iniciativa privada, desde que cumprindo as regras gerais do sistema de ensino nacional, autorização prévia para o exercício e capacidade para o autofinanciamento. Esses documentos legais buscaram organizar e preencher lacunas e defasagens sociais nas políticas públicas direcionadas para vencer as barreiras do analfabetismo, que em pleno século XXI não são mais aceitáveis. 
O sistema educacional brasileiro apresenta um quadro de rupturas em função de imediatismos políticos, em que as necessidades da população nem sempre são prioridade na elaboração dos ordenamentos jurídicos que regem nossa vida diária. Assim,Bello 2001 (afirma que

A situação atual, criada pela sucessão periódica de reformas parciais e frequentemente arbitrárias, lançadas sem solidez econômica e sem uma visão global do problema, levou a educação brasileira a evoluir em saltos desordenados, em diversas direções. (2001, s. p.)

A expansão do atendimento à demanda educacional já teve vários focos, dependendo de influências internacionais, que impuseram normas e padrões de qualidade a serem atendidos e paulatinamente construídos. $\mathrm{O}$ regime militar priorizou o capital humano, tão necessário às indústrias nacionais, a Organização das Nações Unidas para a Educação, a Ciência e a Cultura (UNESCO) privilegiou o Ensino Fundamental, em que todas as crianças, a partir de 6 anos de idades, teriam que estar matriculadas em escolas públicas. Já a Educação Infantil, passou a ser estruturada a partir da Lei de Diretrizes e Base da Educação Nacional (1996) e foi também na Lei de Diretrizes e Bases da Educação Nacional (LDB), no seu art. 37, que determinou o incentivo, em todos os níveis de ensino, à educação a distância, como forma de garantir o acesso à graduação e formação continuada, bem como a elevação global da escolaridade da população, melhoria da qualidade do ensino e redução das desigualdades sociais e regionais no tocante ao acesso e à permanência da população.

De fato, a partir da década de 1990, o Ministério da Educação (MEC) através de vários programas e ações credenciou instituições públicas e privadas autorizando-as a oferecerem cursos a distância. Parcerias e Consórcios envolvendo as maiores universidades do país foram firmados. Segundo o Censo Inep/MEC 2012, 1.113.850 (um milhão, centro e treze mil e oitocentos cinquenta) alunos de educação a distância conseguiram formação superior, além de atualização profissional para vários profissionais e especialização para outros que há muito não buscavam algum tipo de complementação educacional e profissional. 
A globalização impôs a necessidade do contínuo desenvolvimento de capacidades e competências para enfrentar as transformações mundiais. $\mathrm{O}$ desenvolvimento através das Tecnologias da Informação e da Comunicação (TICs) alterou a concepção tradicional de educação. Devido ao envolvimento de instituições renomadas na formação de profissionais para área, cursos de web designers, designers instrucionais e tutores foram ofertados por essas instituições, houve também o estabelecimento de padrões mínimos de qualidade para a implementação desses cursos. A educação a distância deixou de ser vista como uma modalidade inferior e observou-se o fortalecimento dessa modalidade de ensino, a EAD.

Ao introduzir novas concepções de tempo e espaço, a educação a distância passou a ter importância estratégica nas políticas públicas educacionais, passando a contribuir para sanar defasagens educacionais históricas, proporcionando mudanças significativas na vida acadêmica do país.

Em função desse perfil, a Educação a Distância tem sido apontada como modalidade a ser utilizada preferencialmente na Educação de Jovens e Adultos - EJA, como forma de reduzir a evasão e infrequência, e também para desenvolver nos alunos o conceito de educação para a vida, integrando-os às políticas educacionais fomentadas pelos poderes públicos federativos, Ens (2012, p.7) afirma

[...] que ao longo da história, as políticas públicas tratam a EJA de maneira isolada, vários programas são desenvolvidos para esta modalidade de ensino, mas sempre de maneira pontual e não como um processo $[\ldots]$

Muitos foram os programas direcionados para a população jovem e adulta, principalmente associando-os a educação profissional e cursos profissionalizantes. É um alunado heterogêneo, marginalizado, que necessita de materiais didáticos e técnicas pedagógicas apropriadas, além da especialização do corpo docente.

Os problemas relacionados à evasão escolar muitas vezes são tratados pelos órgãos governamentais como sendo de responsabilidade do 
próprio aluno, atribuindo a eles a culpa por suas dificuldades de aprendizagem e fracasso escolar (apud Arroyo, 2003), fala-se de aluno evadido, não de aluno excluído. Fala-se de fracasso do aluno, não do fracasso da escola. Nesse sentido, quando o estado responsabiliza o educando pelo seu fracasso, considerando somente as questões individuais, esquece que estas são provocadas por fatores de ordem socioeconômica, que deixam ainda mais evidentes as desigualdades (ENS, 2012, p.5).

A integração dos programas de educação de jovens e adultos com a educação profissional aumenta sua eficácia, tornando-os mais atrativos, recentemente alguns programas como o Projovem Urbano, Proeja e Formação Inicial Continuada (FIC), passaram a conceder auxílio financeiro mensal aos jovens atendidos, durante $o$ desenvolvimento do curso, no valor de $\mathrm{R} \$ 100,00$ (Cem Reais) condicionado a 75\% de presença deste jovem nas atividades presenciais e a entrega de trabalhos pedagógicos, como forma de conter a evasão.

A União, atuando no âmbito da educação de jovens e adultos sob a forma de assistência técnica e financeira, assume, por meio dos Institutos Federais, seu papel de articuladora, exercendo a função supletiva determinada na Carta Magna, visando impedir descontinuidades e induzir ações continuadas e integradas entre os diferentes entes federativos, FIC-Formação Inicial e Continuada. Ao analisarmos os programas voltados para essa modalidade, EJA, percebemos a presença constante dos órgãos federais em programas e projetos.

O fator financeiro tem sido preponderante e também um ponto de conflito nos programas e políticas públicas educacionais, o PROJEA FIC, conforme disposto no Ofício Convite, teve a descentralização por turma de trinta (30) alunos, o valor de sessenta e cinco mil reais $(\mathrm{R} \$ 65.000)$ no ano de implantação. Esse valor deveria ser investido em material de consumo, laboratório de formação básica, aquisição, modernização ou adaptação de laboratórios de educação profissional (exceto obras), material bibliográfico, pagamento de pessoa física para execução do curso de formação do PROEJA FIC, diárias e passagens para professores do curso formação de formadores e pagamento de pessoa física e jurídica para design, diagramação e impressão, sendo os 
recursos liberados não para os municípios e sim para os Institutos Federais, órgão encarregado da implantação dos módulos profissionais.

Os profissionais administrativos, corpo docente, merenda, transporte, os espaços para utilização nas aulas do módulo regular, bem como no módulo profissionalizante foram de responsabilidade do município, ou seja, não receberam recursos, mas tiveram despesas. Não podemos desconsiderar que o item recurso financeiro é um fator motivador e o equilíbrio das contas públicas depende dele. É de suma importância a existência de uma fonte permanente de recursos a fim de viabilizar a participação efetiva municipal nos projetos federais que, comparado ao ensino regular é mais dispendioso o custo aluno/EJA, apresentando-se como um obstáculo ao desenvolvimento da integração das modalidades.

Embora oneroso financeiramente -e qualquer política de inclusão social o é-a convergência entre EJA e EAD, de forma exitosa, não poderáse furtar a estruturar práticas pedagógicas que ampliem e problematizem a inserção dos sujeitos na realidade objetivas dos sujeitos. PACHECO (2011, pag.6)

A remessa de verbas para as unidades escolares é determinada por dois índices educacionais: Censo Escolar e IDEB. O levantamento desses dados traça um panorama nacional, servindo de base para gerenciar programas com transferência de recursos públicos e execução de programas na área de educação, como o FUNDEB, Dinheiro Direto na Escola, o Mais Educação, PDE, etc. , coordenado pelo Instituto Nacional de Estudos e Pesquisas Educacionais Anísio Teixeira (Inep), realizado em todo território nacional em parceria com as secretarias de educação estaduais e municipais, com participação de todas as escolas públicas e privadas do país, abrangendo todas as modalidades e etapas do ensino. O valor que cada município e estado recebe depende da arrecadação e do número de matrículas da rede. A União complementa quando esse repasse não atinge o valor mínimo estabelecido nacionalmente para cada aluno ao ano em 2010 foi de $R \$ 1.414,85$. 
A educação a distância ainda não foi incluída nesses índices, consequentemente não há repasse de verbas para a EAD. Na EJA consta, sendo repassado o valor determinado nacionalmente pelo MEC, até 2005, que os alunos dessa modalidade tinham o repasse de $80 \%$ do Fundo de Manutenção e Desenvolvimento da Educação Básica (FUNDEB).

Os alunos dos cursos semi-presenciais de Educação de Jovens e Adultos e dos cursos a distância não têm direito aos recursos do FUNDEB, pois esses alunos não são Registrados no Censo Escolar/INEP/MEC, critério exigido para que os sistemas de ensino recebam recursos desse fundo.

É dever do Estado oferecer o ensino fundamental de forma gratuita e universal, a LDB (1996) considerou a EJA como modalidade do ensino fundamental, ou seja, responsabilidade municipal. Os Estados passaram a atuar prioritariamente no ensino médio, a tendência atual é a redução da sua presença nos anos iniciais da educação básica.

O Ministério da Educação coloca a questão da seguinte forma:

Os Municípios, ora com mais e maiores encargos no âmbito da educação básica, não possuem uma realidade homogênea nem quanto ao seu tamanho, nem quanto à sua inserção em diferentes regiões e contextos. Assim, é preciso reconhecer que muitos, seja por falta de tradição na área, seja por carência de recursos, não estão tendo capacidade e condições de assumir os encargos que lhes foram atribuídos. (Parecer CNE/CEB 11/2000).

Esses dados mostram que o item financiamento provavelmente necessitará ser revisto para que os municípios possam investir de fato nessa nova modalidade, $\mathrm{EJA} / \mathrm{EAD}$, que a principio exigirá investimentos, treinamentos e viabilidade técnica para sua plena execução, mostrando a necessidade de uma política integrada, contínua e cumulativa entre os entes federativos, financiada com recursos suficientes e identificáveis visando sua sustentabilidade. 
As pesquisas levaram a trabalhos acadêmicos os quais enfatizam pontos que fragilizam a EJA, colocando a EAD como solução para a democratização do ensino e solução para a precarização da oferta de EJA, muitos alertam para a transferência de experiências educacionais sem uma adequação ao público destinado, fato corrente nos cursos pesquisados no presente estudo de caso, se a EAD "exige uma nova postura educacional do docente, do discente, dos gestores e da instituição de ensino" (DUARTE, 2011, p.6), como a convergência pode ser construída sob projetos educacionais sólidos?

VILHENA, 2012, salienta:

Seguramente, a educação a distância, é uma alternativa de democratização da educação brasileira, mas precisa estar constituída de objetivos, conteúdos e resultados explícitos, reconhecidos pelos sistemas de ensino como educação, tal qual o ensino presencial, ou seja, como projeto educacional e como processo de desenvolvimento individual e social. (2012, p. 41)

A ausência de propostas pedagógicas para a EJA torna a modalidade um desencontro didático, "sendo formulada e reformulada, continuamente, ao sabor de rupturas políticas, criando uma desconfiança por parte da população, mesmo quando há compromisso por parte dos dirigentes do Estado.” (SILVA 2009, p.6).

A necessidade de formação múltipla, a mobilidade dos cursos, as políticas de formação de pessoas adultas deverão ser necessariamente abrangentes, diversificadas e altamente flexíveis, sendo assim,

[...] os objetivos da formação de pessoas jovens e adultas não se restringem à compensação da educação básica não adquirida no passado, mas visam a responder às múltiplas necessidades formativas que os indivíduos têm no presente e terão no futuro. (DI PIERRO 2001, p. 70) 
A questão que se coloca como desafiadora, no entanto, é pautar esse tipo de oferta de ensino em padrões de qualidade que permitam uma formação não somente voltada para o mercado de trabalho, mas para a vida, que permita o desenvolvimento integral do ser humano.

É necessário destacar, no entanto, que o modelo de Educação a Distância apresentado como uma alternativa ao acesso à escolarização de jovens, adultos e idosos, espalhados por todo o Brasil, deve se pautar pela qualidade. Qualquer modalidade educacional que se pretenda elevar o nível de escolaridade do povo brasileiro tem que se preocupar com a formação deste enquanto cidadão, e não apenas como decodificador de linguagens ou detentor de um diploma. $\mathrm{O}$ acesso à educação deve garantir aos educandos elementos que os permitam reconhecer seus direitos e deveres na sociedade, assim como se perceber como agente transformador e sujeito histórico.(COURA, ARAÚJO, 2010, p. 13)

A consolidação vivenciada pela educação a distância poderá ser transferida para a EJA, conforme Antunes (2014) alerta: "existem muitas possibilidades da educação continuada para os alunos, desde que as organizações estejam preparadas para atender as diferenças e os anseios de jovens e adultos.”

A flexibilização pedagógica e administrativa necessária à implantação da modalidade EJA/EAD, objeto de estudo deste trabalho, torna-se um desafio para profissionais e instituições. $\mathrm{Na}$ educação a distância, parcerias e consórcios fortalecerem-na e tornaram-na uma referência no ensino superior. De acordo com DUARTE:

A maior parte das instituições começa oferecendo cursos a distância de forma isolada e com alcance predominantemente regional, mas há atualmente uma evolução forte para a formação de associações pontuais ou mais estáveis, como os consórcios. Há, ainda, uma mobilização grande das universidades públicas - que se unem pressionadas pelo governo federal, para participar de projetos de 
formação de professores através da UAB - Universidade Aberta do Brasil - e de cursos na área de administração em convênio com empresas estatais inicialmente, (DUARTE, 2011, p.25)

Nesse prisma, a adequação das políticas públicas faz-se necessária, pois se na educação superior foi preciso a formação de parcerias e consórcios com grandes universidades para permitir o oferecimento de ensino de qualidade, esperar que o poder público municipal, sozinho, consiga solucionar uma defasagem histórica do EJA é ingênuo e mostra como as políticas públicas percorrem um longo caminho entre a teoria e a prática.

De acordo com ENS: "Diversas são as propostas idealizadas em gabinetes para a EJA, mas na prática tudo é diferente. A estrutura para receber esses alunos é precária, o currículo é fora de contexto e os professores não têm formação adequada”. (2012, p.12)

Há uma particularidade que A EJA tem assumido, recentemente, uma particularidade que precisamos abordar e provavelmente tornará a implementação da modalidade EJA/EAD mais desafiadora, o perfil dos alunos tem rejuvenescido gradativamente. $\mathrm{O}$ fracasso escolar tem atingido alunos cada vez mais jovens. De acordo com Brunel:

\footnotetext{
Alguns anos atrás, o aluno que frequentava esta modalidade tinha parado há muito tempo de estudar, era mais velho e o objetivo maior era terminar o Ensino Fundamental e Médio com vistas a um melhor emprego ou a promoção no seu local de trabalho. Atualmente, eles são mais jovens, muitos pararam há pouco tempo de estudar são recémegressos da escola regular e a maioria possui um histórico de repetência de um ano, dois anos ou mais. (2002, p.2)
}

O ensino regular fundamental é responsabilidade municipal, como já mencionado anteriormente neste trabalho, devendo ser oferecido a alunos até o $9^{\circ}$ ano, então, a faixa etária a ser atendida é dos 6 (seis) a 15 (quinze) anos de idade, a partir dessa idade o aluno já pode frequentar cursos noturnos. 
O que observamos nas unidades escolares é o forte aumento da distorção série/idade do $6^{\circ}$ ano em diante, quanto mais ela avança, maior é a dificuldade de convivência do aluno na sala de aula e também da incapacidade do professor ensinar, afinal o conteúdo pedagógico oferecido é o mesmo, independente do fato de haver um aluno com 12 (anos) ou 16 (dezesseis) anos. A necessária contextualização torna-se um desafio para gestores, orientadores e professores.

Brunel afirma que "a trajetória escolar desses jovens, caminho este atravessado por "situações de fracasso escolar", pelo desencanto com a escola 'regular', com as políticas públicas, pelos problemas sociais, econômicos e pessoais [...]” (2002, p.10) levam a migração maciça para a modalidade EJA. E continua:

Atualmente, pensar na Educação de Jovens e Adultos (EJA) como modalidade de ensino que atende adultos e idosos que buscam a alfabetização é um equívoco, pois muitos dos jovens que frequentam a EJA são adolescentes que, por diversos motivos, abandonaram o ensino regular, talvez por uma frequente repetência e a pressa em escolarizar-se, devido às exigências do mercado de trabalho e à necessidade de inserção na sociedade (apud Brunel, 2004), o fenômeno do rejuvenescimento nesta modalidade de ensino começou a surgir no panorama brasileiro a partir dos anos 90. ENS (2012, p.1)

Portanto, temos convivido dentro do ambiente escolar na modalidade EJA, os chamados nativos ${ }^{1}$ e migrantes digitais, ou seja, em termos de TIs e ensino através das Ambientes Virtuais de Aprendizagens (AVAS), os externos estão presentes nos cursos e terão que ser atendidos por propostas pedagógicas que possibilitem adaptações e integração a EAD.

$\mathrm{Na}$ esteira desse processo, a educação a distância tem contribuído de forma relevante na educação de um grande público essencialmente, no ensino superior. E isso

\footnotetext{
${ }^{1} \mathrm{Um}$ nativo digital é aquele que nasceu e cresceu com as tecnologias digitais presentes em sua vivência. Tecnologias como videogames, Internet, telefone celular, $\underline{\mathrm{MP} 3}$, $\underline{\mathrm{iPod}}$, etc. 5. Caracterizam-se principalmente por não necessitar do uso de papel nas tarefas com o computador. FONTE: http://pt.wikipedia.org/wiki/Nativo digital.
} 
faz com que essa modalidade seja alvo de vários estudos na tentativa de se conhecer e expor suas qualidades, sendo de suma importância na formação do cidadão.

Por outro lado, alguns fatores influenciam no ensino-aprendizagem dos alunos inseridos nessa modalidade de ensino, em que o mesmo tem que ser autônomo em busca do conhecimento participativo nas discussões dos fóruns e atividades propostas.

Segundo Silva (2004, apud CARVALHO, 1994), algumas dentre várias vantagens da aprendizagem autônoma permite ao aluno aprender melhor, por buscar maior aprofundamento nos assuntos de seu interesse; contribui para enriquecer os conhecimentos dos alunos; o aluno aprende a se libertar da dependência do professor e passa a descobrir formas alternativas de construir o conhecimento. Silva (2004,s.p.), destaca que nessa "aprendizagem autônoma pode-se reconhecer três componentes que desempenham importante papel em todo o processo: o componente do saber, o do saber fazer e o do querer".

De acordo com Oliveira (2006), aluno precisa estar focado em aprender e reaprender sempre, ou seja, quando necessário, reconstruir conceitos diante de novos paradigmas, pois "Quando falamos de construção do conhecimento, o fazemos não somente no sentido do conteúdo a ser conhecido, mas também das bases epistemológicas e metodológicas". Ressalta que é preciso estar disponível à discussão, questionar sempre quando não entender ou discordar, buscar por mais conhecimento; tem que ser um desafio constante, tendo em vista o somatório de vários aspectos, uma vez que "elementos conscientes e inconscientes incorporam muitas coisas que ajudam a definir as pessoas como indivíduos"(FONTANA, 2002, p. 199).

Assim como na modalidade presencial, ocorre, na modalidade a distância, a evasão, sendo esta considerada um desafio. Faria et al 2014, Pg. 02-09 destaca que a evasão universitária tem se caracterizado como uma realidade recorrente no âmbito do ensino de graduação em várias partes do mundo. No caso dos cursos a distância, os índices de evasão são expressivamente maiores do que nos cursos presenciais. Outro resultado importante, destacado pelas autoras acima, é que o motivo de desistência nos cursos presenciais se deve a fatores socioeconômicos; nos cursos a distância, a esses fatores se somam diversos outros, com igual ou maior importância. Os cursos a distância apresentam diversos aspectos que propiciam flexibilidade aos alunos, mas também 
possuem desafios a serem superados, como a dificuldade para acompanhar um cronograma de estudos, problemas com a tecnologia necessária para um melhor aproveitamento e a necessidade de autonomia do estudante para coordenar sua aprendizagem. Isso pode levar os alunos a desistir do curso sem o concluir.

Almeida (2008), ao analisar os motivos de desistência de um curso EAD de especialização, classifica em cinco categorias principais o porquê os alunos abandonam o curso. A primeira categoria refere-se aos fatores situacionais que ocorrem durante o curso e que podem levar o aluno à evasão. Entre esses fatores, a autora cita a falta de apoio no trabalho, curso simultâneo, problemas familiares e falecimento de familiares, entre outros. Énesses momentos de tensão que se torna relevante outro fator importante na persistência ou não dos alunos: as características pessoais. Moorey e Kearsley (2008) destacam que os alunos mais propensos ao sucesso em cursos a distância são aqueles menos influenciados pelo ambiente que os rodeia. Os autores acreditam haver ainda relação entre o sucesso e a introversão-extroversão dos alunos, seu perfil e sua personalidade.

A segunda categoria destacada por Almeida (2008) é a falta de apoio acadêmico. Nela estão aqueles alunos que não consideram adequado o apoio acadêmico dado pelo curso.

No entanto, podemos observar que entre as vantagens apontadas para que a EJA se aproprie cada vez mais dos pressupostos da Educação a distância, pode-se destacar o fato de que a EAD estaria pronta a responder mais rapidamente às necessidades de formação para o mercado de trabalho.

A EAD oferece ao aluno trabalhador da indústria a flexibilidade de tempo e de espaço fatores tão necessários para a sua permanência na escola. $\mathrm{O}$ aprendizado pode ocorrer a qualquer hora em qualquer lugar, conforme seu ritmo e necessidade. (MACHADO, 2011, p.6)

Além disso, a possibilidade de associação dessas duas modalidades de ensino pode significar um salto qualitativo e quantitativo de atendimento de jovens e adultos que não tiveram a sua escolaridade na época própria. 


\begin{abstract}
A Educação de Jovens e Adultos e o Ensino a Distância surgem como formas de empoderamento destes indivíduos e como uma opção de inclusão para todos os que se reconhecem como sujeitos participantes e transformadores dessa sociedade globalizada, prontos a apropriar-se das tecnologias educacionais como mediadoras no seu próprio processo de ensino-aprendizagem. (MUNOZ, PEREIRA, LIMA, 2010, p. 22)
\end{abstract}

\title{
Resultados
}

Os Estudantes inseridos na Educação de Jovens e Adultos (EJA) são alocados em turmas identificadas por fase. $\mathrm{O} 6^{\circ}$ ano, fase $\mathrm{V}$, corresponde a $5^{\circ}$ série, $7^{\circ}$ ano, fase VI, corresponde a $6^{\circ}$ série; $8^{\circ}$ ano, fase VII, corresponde a $7^{\circ}$ série; $9^{\circ}$ ano, fase VIII, corresponde a $8^{\circ}$ série.

As escolas apresentam um espaço físico em boas condições e de fácil acesso a portadores de necessidades especiais, que são acompanhados por profissionais especializados. As aulas se iniciam as 18 horas e 30 minutos, mas antes é oferecido cardápio escolar diversificado preparado por nutricionistas. O término da aula é previsto para 21 horas e 30 minutos.

Em três Escolas Municipais na cidade de Barra Mansa, que oferecem a Educação de Jovens e Adultos (EJA), na modalidade presencial, no período noturno, onde a alfabetização é realizada em dois semestres e as demais séries são semestrais, dividida por fases, foram aplicados 112 questionários. Antes da aplicação da ferramenta de pesquisa, os estudantes foram sensibilizados a respeito da mesma, com ênfase na Educação a distância (EAD). Nas três unidades de ensino amostradas na pesquisa, observou-se de forma significativa a presença de estudantes do sexo masculino em detrimento aos do sexo feminino, como mostra o gráfico 1. 
Gráfico 1 - Número indivíduos por sexo na Educação de Jovens e Adultos.(EJA)

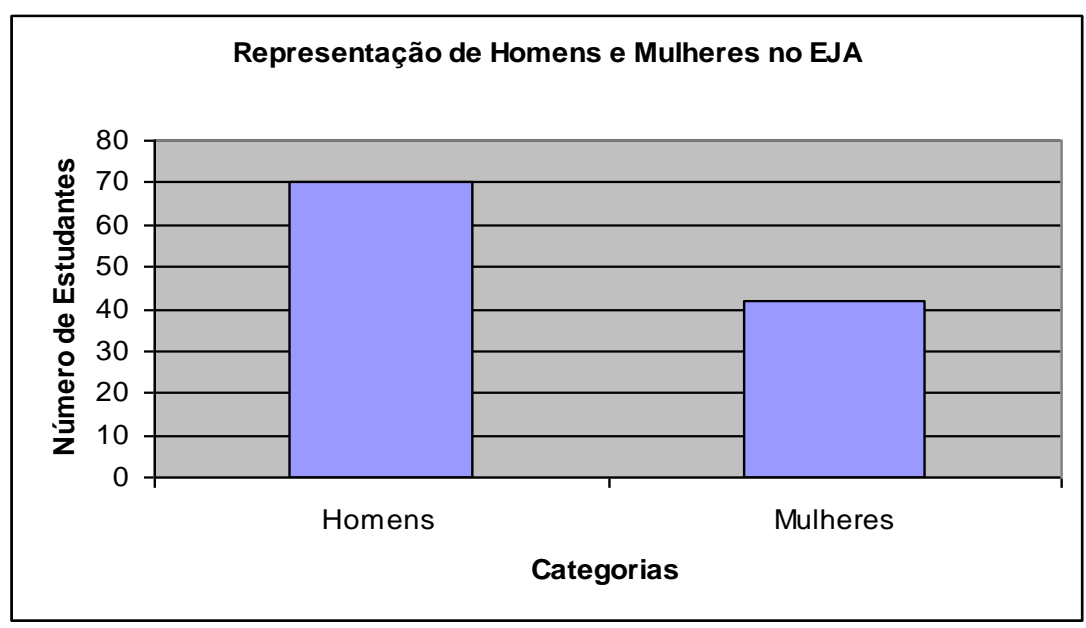

Fonte: Tânia Cristina

A diversidade entre os estudantes do EJA se faz presente, tanto na idade, quanto no gênero. Os dados compilados demonstram que estudantes do sexo masculino e feminino são considerados jovens e a maioria se encontra com idade entre 15 a 17 anos, sendo que a presença de homens é mais acentuada, o que pode estar associado ao fato de os mesmos serem excluídos do ensino regular mais cedo do que as mulheres, por sucessivas reprovações, ou terem que ingressar no mercado de trabalho.

Nos gráficos 2 e 3 podemos constatar existirem diferenças entre jovens e adultos, mas que compartilham semelhanças em ambos os sexos, a presença de jovens do sexo masculino é significativa em relação os jovens do sexo feminino. Tal situação nos leva a pensar que esses jovens de certa forma foram excluídos da educação básica. São aqueles alunos que, como afirma Pierre Bourdieu, podem ser considerados os excluídos do interior, pois, de alguma forma, no interior da escola não puderam ou não conseguiram se adequar ao sistema escolar. Isso pode ser observado através da indisciplina, da negação, da agressão, das recorrentes reprovações e da desistência. Contudo, para sobreviver e ser aceito socialmente, no mundo atual, os sujeitos têm que se adaptar a outras regras, sobretudo as do mercado de trabalho que por sua vez só abre as portas para aqueles que têm um determinado nível de escolarização. Dessa forma, esses 
estudantes ingressam na Educação de Jovens e Adultos, por vontade ou por indicação dos familiares, reconhecendo a importância da continuidade dos estudos, assim encontram na EJA as possibilidades de conclusão.

Gráfico 2 - Idade dos estudantes do sexo masculino na Educação de Jovens e Adultos( EJA).

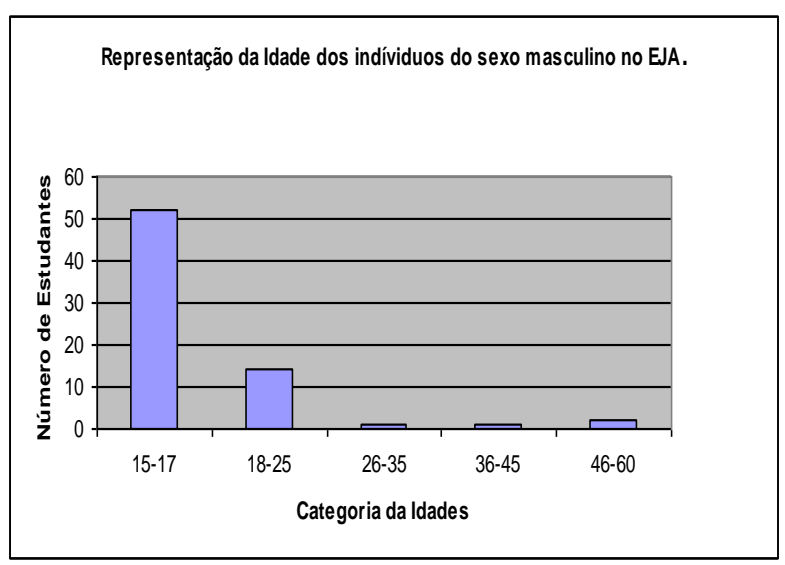

Gráfico 3 - Idade dos estudantes do sexo feminino na EJA

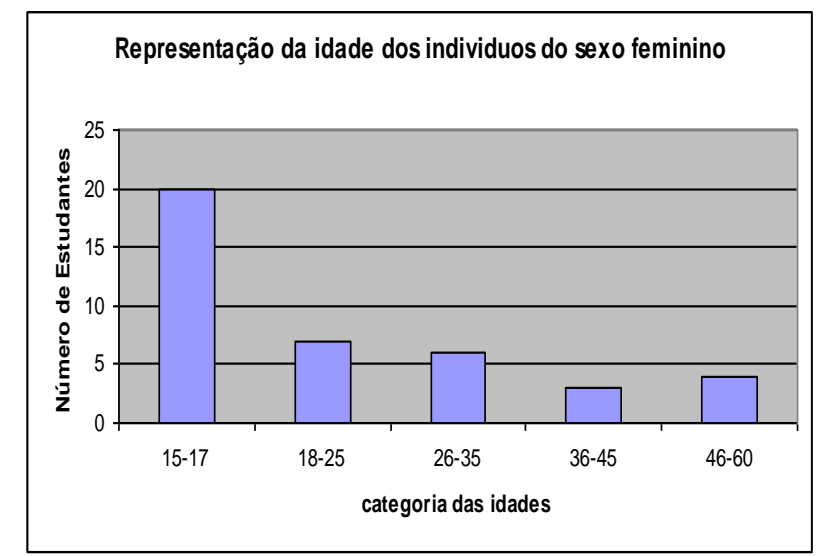

Gráfico 4 - Nível de conhecimento da EAD pelos estudantes da EJA

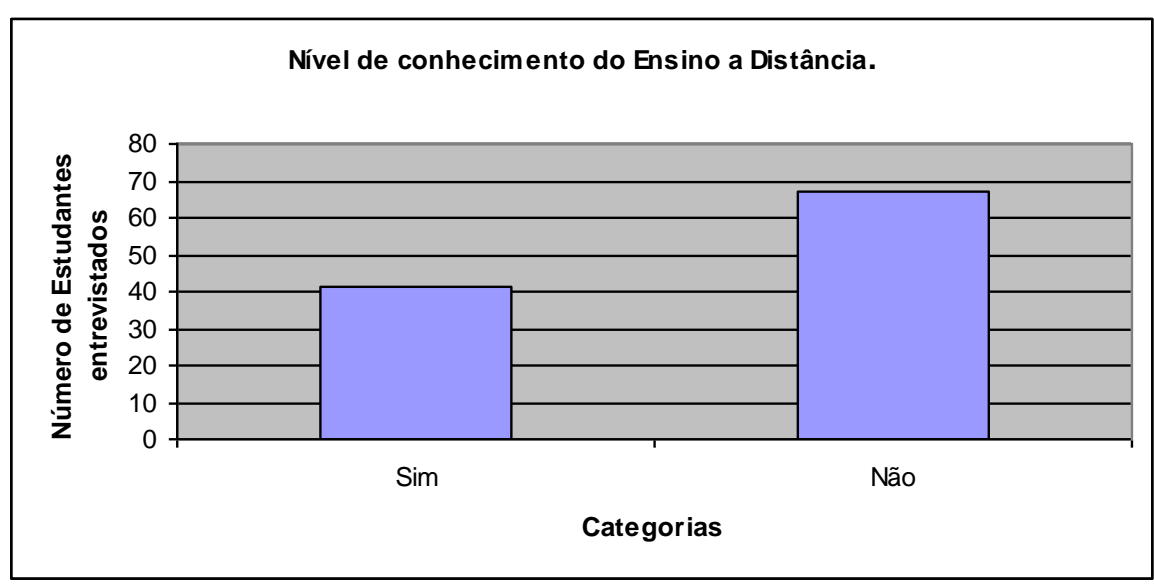

Fonte: Tânia Cristina

Os sujeitos do EJA como ilustra o gráfico acima (4),grande parcela desconhece a metodologia de ensino a distância, mas a escola entrevistada possui em suas 
dependências laboratório de informatica, onde se poderia oferecer u m curso de extensão acadêmica ou debates com participação em fóruns, blogs e chats, ou até mesmo aulas de reforço para que os mesmos pudessem conhecer a metodologia.

Sendo assim poderiamos unir educação a distância à educação presencial, integrando as metodologias e apresentando a modalidade a distância aos poucos na tentativa de resgatar o interesse e diminuar a infrequência e evasão.

Os gráficos abaixo expressam a opinião dos estudantes em relação ao nível de dificuldades e prática em utilizar computador e podemos observar que tanto os homens e mulheres demonstram não conhecer a utilização, mesmo tendo computador em casa, como mostra o gráfico 5 e 6 . Logo, a autora acredita que pelo fato de não ser preciso sair da residência em busca de locais para utilização das tecnologias, já possibilita a pesquisa e para o futuro o conhecimento e participação de cursos na modalidade a distância.

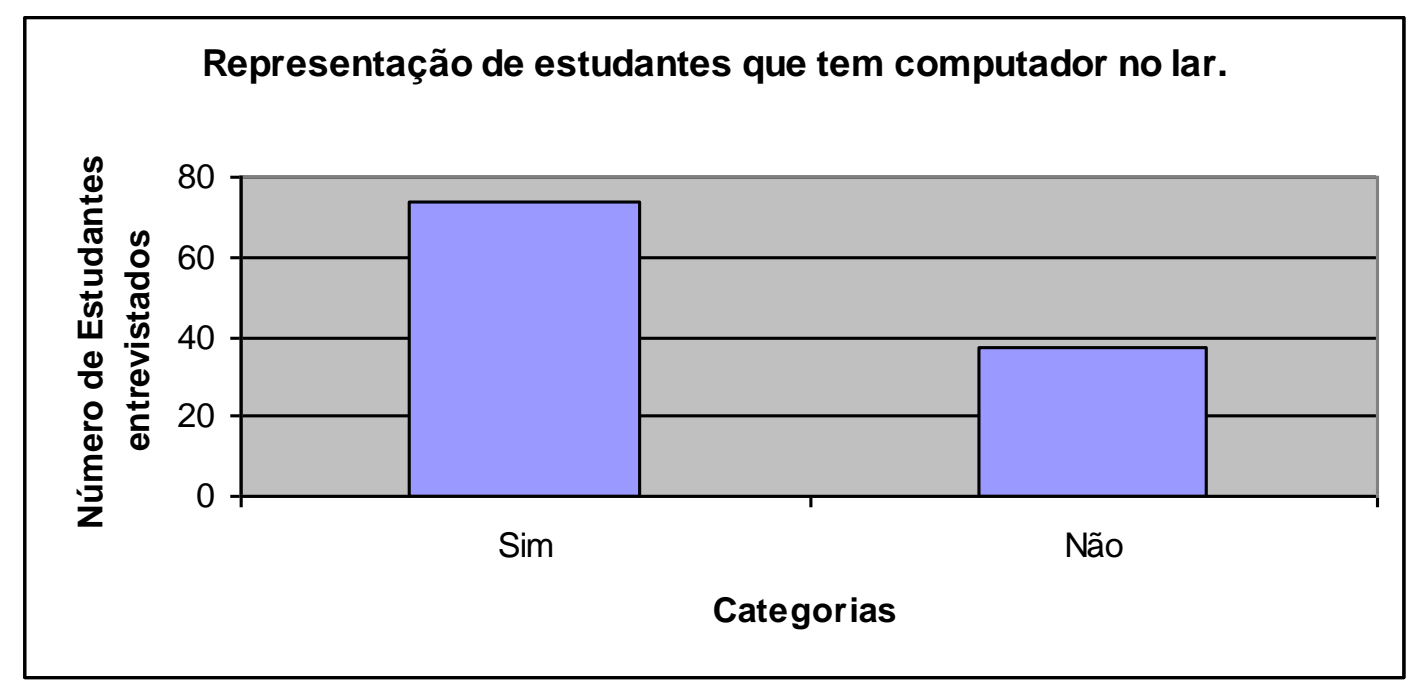

Fonte: Tânia Cristina 


\section{Representação do nível de conhecimento e prática na utilização de com putador.}

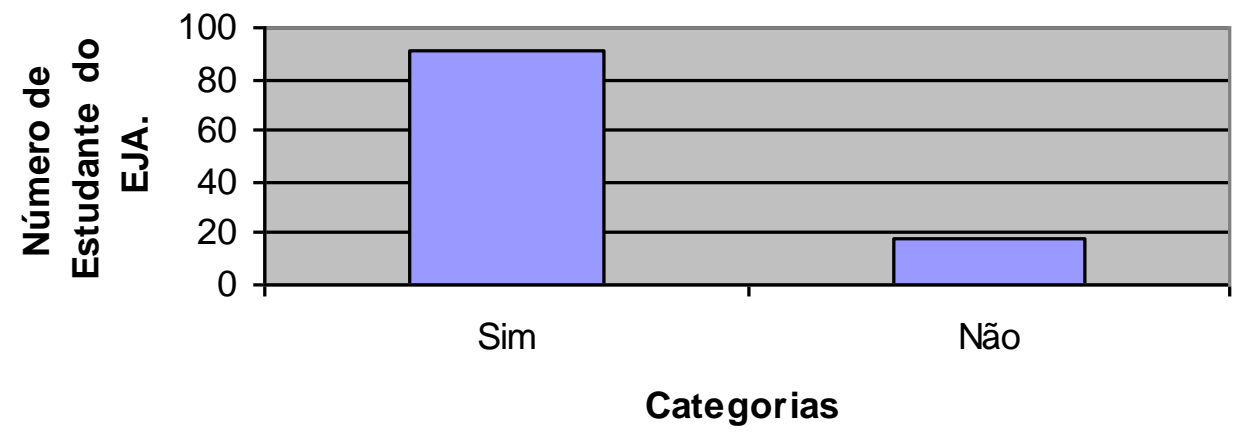

Fonte: Tânia Cristina

Apesar do domínio no manuseio de aparelhos de telefonia móvel e tablets, muitos não sabem manusear computador, talvez essa situação apontada seja obstáculo para o ingresso na educação a distância.

Não tem prática de utilizar computador e veem dificuldades de estudo através do mesmo, devido ao horário e outros recursos didáticos, sendo que muitos não estudam quando não estão inseridos no ambiente escolar.

Gráfico 7-Benefícios da EAD na EJA 


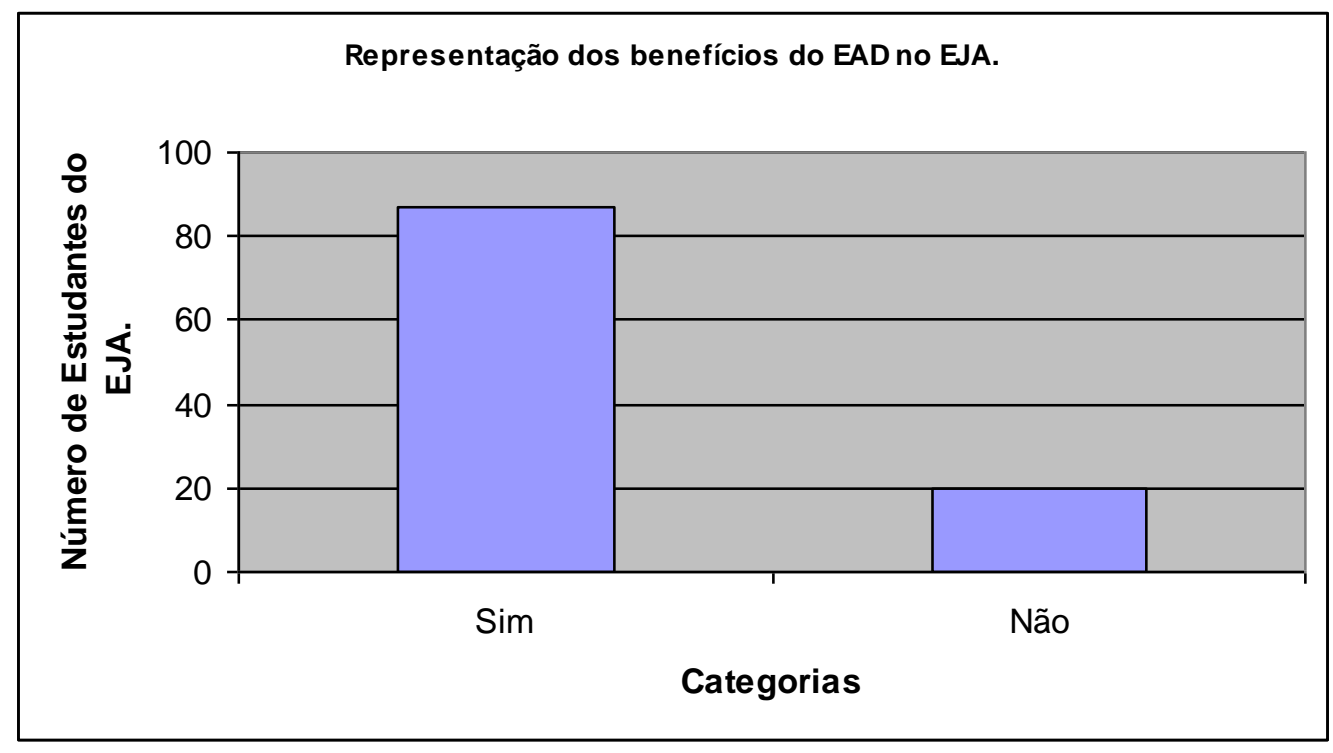

Fonte: Tânia Cristina

A educação a distância e as possibilidades de implementação na Educação de Jovens e Adultos, com sua flexibilidade e acessibilidade, poderia agregar benefícios na vida dos estudantes, como otimização de tempo, permitindo tempo para estudar, trabalhar e exercer outras atividades diárias e dar atenção a família.

Gráfico 8 - Dificuldades em relação à EAD na EJA para o sexo masculino.

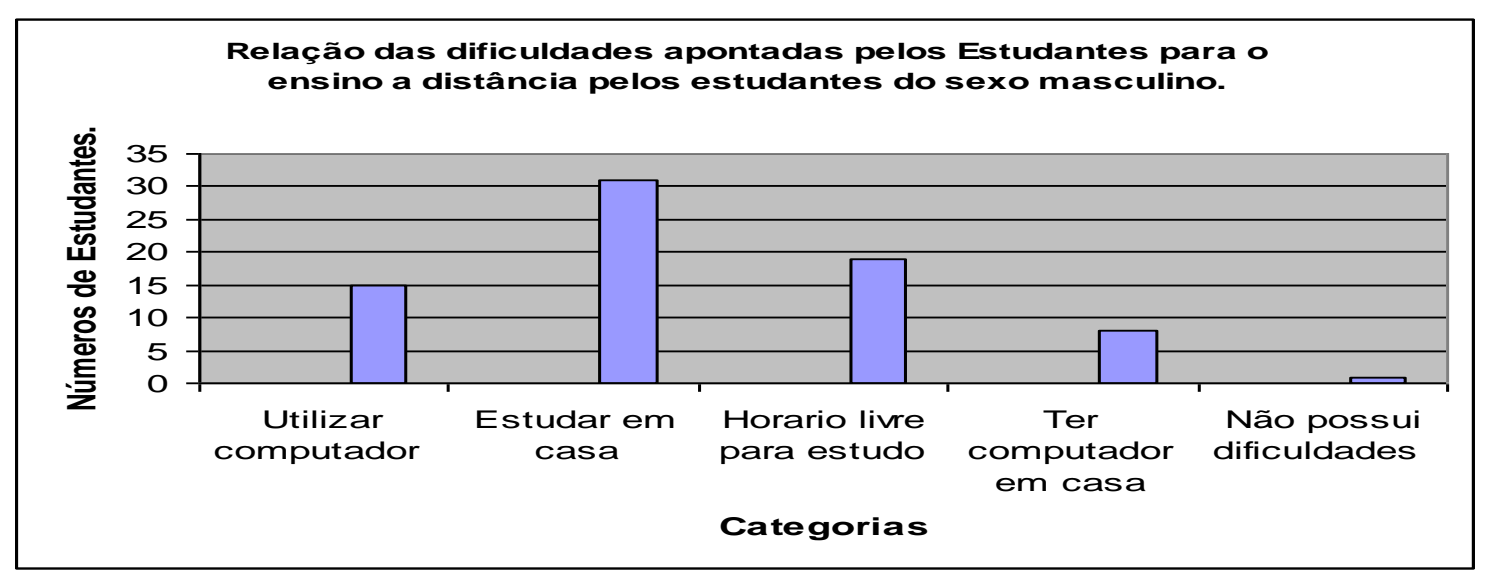

Fonte: Tânia Cristina 
Gráfico 9- Dificuldades em relação a EAD na EJA para o sexo feminino.

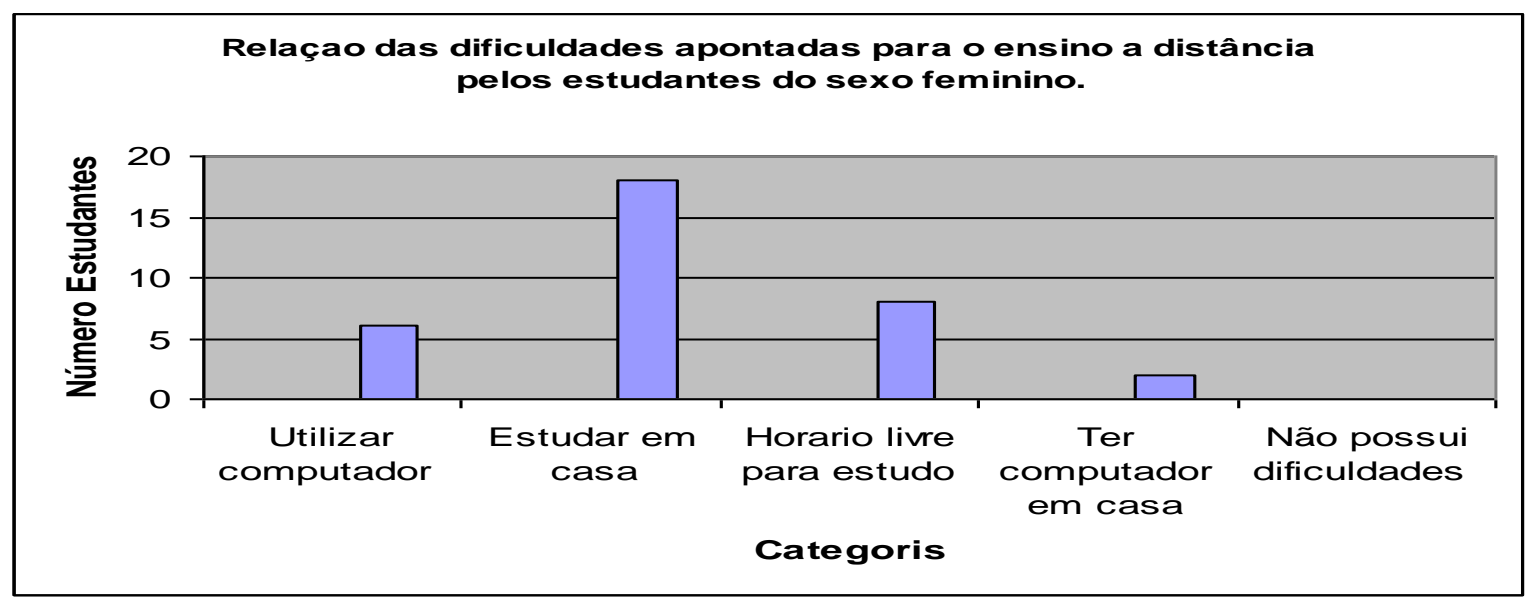

Figura 1

Fonte: Tânia Cristina

Em resposta aos questionamentos das dificuldades do ensino a distância, os estudantes do EJA de ambos os sexos, apontam com relevância como mostra o gráfico 8 e 9, que estudar em casa será um obstáculo, impossibilitando o ingresso nesta modalidade, pois não terá a presença do professor, e sim do mediador. Já que os mesmos só estudam quando estão na escola na modalidade presencial. Como mencionado anteriormente, muitos têm computador em casa, mas por motivos desconhecidos não utilizam e não têm interesse em manusear.

Como é sabido, os estudantes do ensino a distância têm em seu perfil, um dos pré-requisitos para o sucesso: promover a interação, a autonomia, disciplina para realizar as atividades propostas dentro dos prazos estabelecidos, incluindo dedicar-se em horário livre aos estudos. 


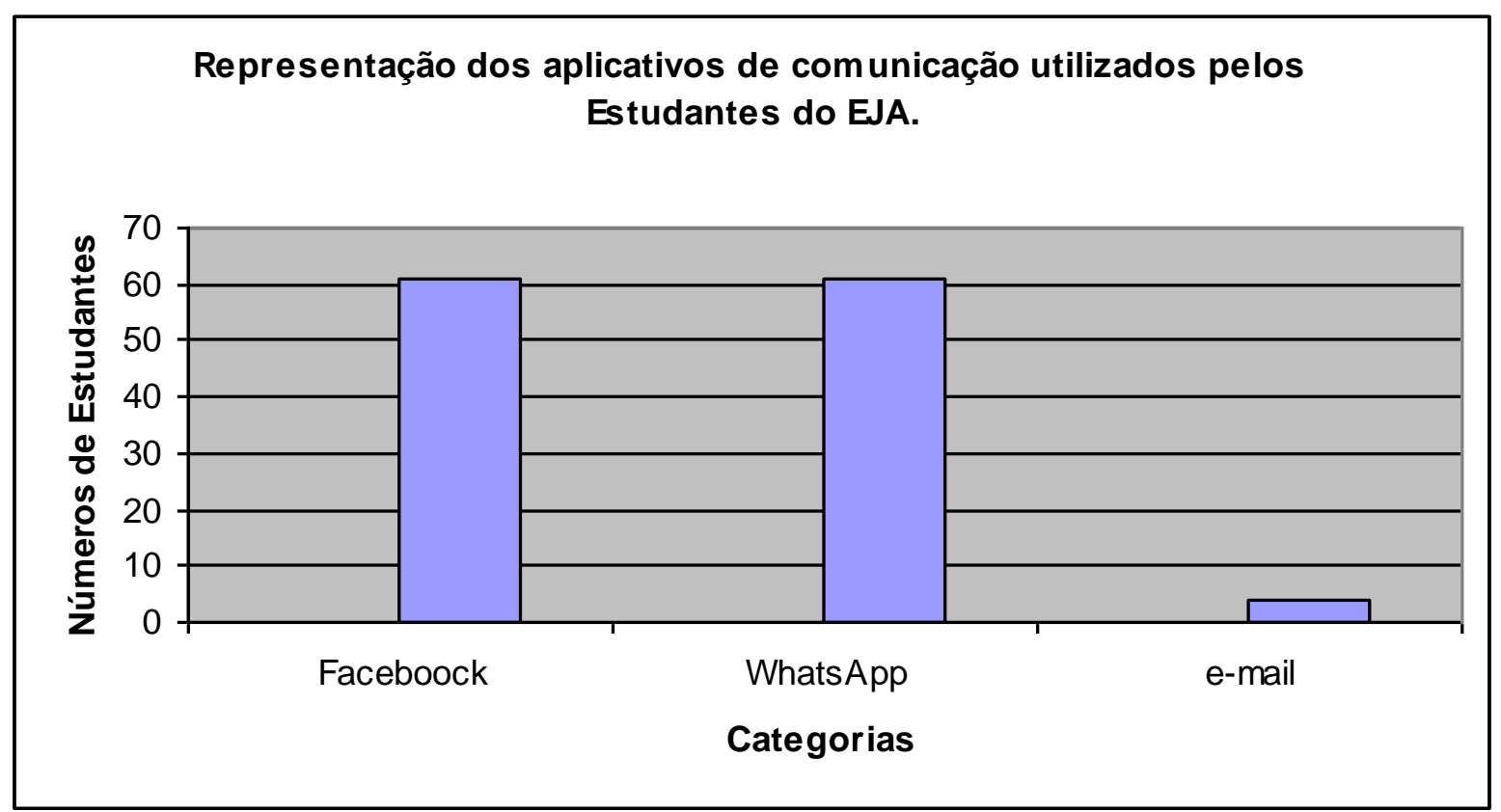

Fonte: Tânia Cristina

Em resposta aos questionamentos pode-se observar que muitos utilizam no cotidiano aplicativos de redes sociais como faceboock e WhatsApp. De fato, eles promovem a interação social, um círculo crescente de amizades, mas desconhecem que através desses aplicativos podem promover a mediação e comunicação síncrona e assíncrona, resultando em aprendizagem, sendo este um dos pilares da educação a distância.

Concomitante, com a aplicação dos questionários, foram feitas entrevistas nas Escolas na tentativa de investigar a visão dos Gestores sobre as possibilidades de implementação da educação à distância na Educação de Jovens e Adultos (EJA).

As entrevistas apontam que, para os gestores, a Educação de Jovens e Adultos (EJA) atrai inúmeros estudantes pelo fato de ser organizada por semestre. Dessa forma, os alunos podem realizar duas séries (fases) em apenas um ano, possibilitando conclusão rápida para o ingresso em cursos profissionalizante ou superior. Mas, mesmo assim, o índice de evasão é elevado, e os estudantes faltam às aulas por um período prolongado e 
retornam sem justificativa a assistir as aulas, com perda de conteúdo, em alguns casos reprovados por falta.

Em relação à implementação da Educação à distância, os gestores apontam como desvantagens a falta de acompanhamento do professor para sanar dúvidas e dar um aprofundamento para estudos futuros; o desinteresse dos estudantes; a falta de organização e motivação e afetividade, que serve como fio condutor no processo de ensino aprendizagem.

Em contrapartida apontam como vantagens a otimização dos estudos, flexibilidade, acessibilidade do horário, o desenvolvimento e dinâmica do curso. O que pode ser interessante, e aceito de forma positiva, pelos jovens nesta modalidade de ensino, devido ao domínio e utilização dos aplicativos de comunicação que, em suma, favorecem o aprendizado e a facilidade de acesso, devido à sua expansão tecnológica.

\section{Considerações Finais}

Os dados compilados na pesquisa - com ênfase em gênero, idade, nível de conhecimento do ensino a distância, conhecimento e prática na utilização de computador, existência de computador em casa, benefícios da Educação a Distância na Educação de Jovens e Adultos e utilização dos aplicativos de comunicação pelos estudantes do EJA - tentam apontar a realidade da modalidade de ensino, que tem em seu público grande diversidade e mostram que a Educação de Jovens e Adultos se faz fundamental para as pessoas que não puderam estudar, sendo a oportunidade de inclusão na vida acadêmica, na sociedade e no mercado de trabalho. Os resultados apontam as fragilidades como infrequência e evasão que podem estar atrelados a problemas pessoais, dificuldades para conciliar o trabalho com atividades escolares

Por outro lado, observa-se um público jovem, com domínio e uso das tecnologias, o que pode oportunizar a implantação e fácil aceitação da educação a distância, mas temos que levar em consideração os adultos, que veem nesta modalidade presencial a oportunidade de conclusão em busca de melhores condições de emprego ou ingresso em ensino profissionalizante ou superior. 
Em relação à educação, em que os sujeitos são pessoas que devemos levar em consideração sua vida e experiências temos que considerar opiniões e investigar situações, a fim de diagnosticar em muitos casos suas atitudes como falta de interesse e motivação, o que pode influenciar em idas e vindas à escola.

Mas as escolas participantes e os Profissionais da educação entrevistados relataram que é grande o empenho em resgatar a autoestima do aluno, o interesse em estar inserido na escola, proporcionando momentos especiais e possibilitando o conhecimento à cultura, ao esporte, à estética e ao lazer.

O diagnóstico das expectativas e percepções dos estudantes do EJA em relação a educação a distância foi realizado, em parceria com a Secretária de Educação da cidade , a fim de implementar um modelo piloto com metodologias práticas da Educação a Distância, em que os tópicos devam ser adotados e aplicados a fim de conhecer os parâmetros sociais, pessoais para mensurar o interesse e afinidade com os estudos na tentativa de desmistificar a visão de educação, as dificuldades e desafios. .

\section{Agradecimentos}

A Secretaria Municipal de Educação de Barra Mansa (SME-PMBM) pela autorização e realização da pesquisa; às Diretoras, Pedagogas, Disciplinarias e a todo corpo administrativo das escolas pelo comprometimento e atenção em me atender e participar da entrevista. Aos Professores que interromperam suas atividades em sala de aula, me concedendo minutos para aplicação dos questionários e aos Alunos, pois sem os mesmos a pesquisa não seria possível.

\section{Referências}

ANTUNES, Verônica Morales. Educação a distância: uma alternativa de formação continuada na educação de jovens e adultos. Disponível em: http://www.cereja.org.br/arquivos upload/veronica $m$ antunes ead alternativa.pdf. Acesso em: 09 jul. 2014. 
ALMEIDA, O. C. S. Evasão em cursos a distância: análise dos motivos de desistência. 2008. Disponível em: <www.abed.org.br/congresso2008/tc/552008112738PM.pdf>. Acesso 24 de Agosto de 2014.

BELLO, José Luiz de Paiva. Educação no Brasil: a História das rupturas.2001. Disponível em: http://www.pedagogiaemfoco.pro.br/heb14.htm. Acesso em 13/08/14.

BRASIL, Cristiane Costa. HISTÓRIA DA ALFABETIZAÇÃO DE ADULTOS: DE 1960 ATÉ OS DIAS DE HOJE, 2005. Disponível em bttp://www.ucb.br/sites/100/103/TCC/12005/CristianeCostaBrasil.pdf Acesso em 25/07/14.

BRASIL. Constituição da República Federativa do Brasil. Brasília, DF. 05 de out. 1988. Disponível em <http://portal.mec.gov.br/index.phpoption=com.content\&view=

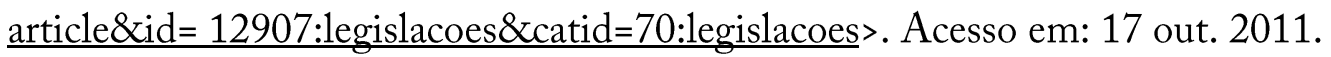

Lei no 9394, de 20 de dezembro de 1996. Estabelece as Diretrizes e Bases da Educação Nacional. Disponível em: $\leq$ http://portal.mec.gov.br/index.phpoption=com

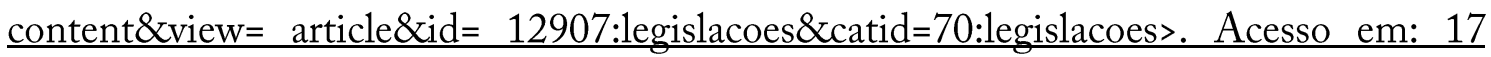
out. 2011.

Lei no 5.540, de 28 de outubro de 1968. Fixa normas de organização e funcionamento do ensino superior e sua articulação com a escola média, e dá outras providências. Disponível em: <https://www.planalto.gov.br/ccivil 03/leis/15540.htm>. Acesso em: 17 out. 2011.

Lei no 5.692 de 11 de agosto de 1971. Fixa Diretrizes e Bases para o Ensino do $1^{\circ}$ e $2^{\circ}$ grau e dá outras providência Disponível em: https://www.planalto.gov.br/ccivil 03/leis15692.htm>. Acesso em: 17 out. 2011.

. Decreto no 5.840, de 13 de julho de 2006. Institui, no âmbito federal, o Programa Nacional de Integração da Educação Profissional com a Educação Básica na Modalidade de Educação de Jovens e Adultos - PROEJA, e dá outras providências. 
Disponível em: http://portal.mec.gov.br/setec/arquivos/pdf/dec584013jul06.pdf $>$. Acesso em: 17 de out. 2011.

. Decerto no 6425 de 04 de abril de 2008. Dispõe sobre o censo anual da educação. Disponível em: https://www.planalto.gov.br/ccivil03/leis15692.htm>. Acesso em: 17 out. 2011.

. Ministério da Educação. Portaria no 931, de 21 de março de 2005. Institui o Sistema de Avaliação da Educação Básica - SAEB. Disponível em: http://www.sinepemg.org.br/legislacao normas gerais.php. Acesso em: 30 dez. 2011.

. Ministério da Educação.Resolução/CD/FNDE no 25, de 24 de maio de 2011. Dispõe sobre a destinação de recursos financeiros nos moldes e sob a égide da Resolução no 17, de 19 de abril de 2011, a escolas públicas da educação básica para a implementação do Plano de Desenvolvimento da Escola (PDE Escola). Disponível em http://www.fnde .gov.br/ index. php/ddne-legislacao. Acesso em 30 dez. 2011.

. Ministério da Educação. Ofício Circular no 40 GAB/SETEC/MEC, de 08 de abril de 2009. Convite às instituições da Rede Federal de Educação Profissional e Tecnológica para implantação do programa nacional de integração da educação profissional com a educação básica na modalidade de educação de jovens e adultos, na formação inicial e continuada com o ensino fundamental (PROEJA FIC). Disponível em: portal.mec.gov.br/index.php? option= comdocman\&task =docdownload\&gid= 1498\&Itemid. Acesso em: 30 dez. 2011.

BRUNEL, Carmem. JOVENS NO ENSINO SUPLETIVO: DESNATURALIZANDO O FRACASSO E RECONSTITUINDO TRAJETÓRIAS. Disponível em http://25reuniao.anped.org.br/excedentes25/carmenbrunelt18.rtf. Acesso em 24/07/14. 
COSTA, S. L. F. ; OLIVEIRA, V. L. L. ; OLIVEIRA, M. C. S.. EAD e EJA: um desafio possível através das TIC. 2010. Disponível em http://www.catedraunescoeja.org/GT12/POS/POS002.pdf. Acesso em 23 jun. 2014.

COURA, Isamara Grazielle Martins. ARAÚJO, Wilson José de. A educação a distância como possibilidade de formação dos sujeitos da EJA. Disponível em: <http://www.senept.cefetmg.br/galerias/Anais_2010/Artigos/GT7/A_EDUCACAO_ A_DISTANCIA.pdf >. Acesso em: 30 jul. 2014.

DE DEUS, A. M; CUNHA, D. E. S. L; MACIEL, E. M.. ESTUDO DE CASO NA PESQUISA QUALITATIVA EM EDUCAÇÃO: UMA METODOLOGIA Disponível em: http://www.lalt.fec.unicamp.br/scriba/files/como produzir/portugues/ANPET\%20 -\%20METODOLOGIA\%20DE\%20ESTUDO\%20DE\%20CASO\%20\%20COM\%20AUTORIA\%20-\%20VF\%2023-10.pdf. Acesso em 06/10/2014.

DE LIMA, MARIA DALVANEIDE (2010) EVASÃO DE EDUCAÇÃO DE JOVENS E ADULTOS NO PROGRAMA BRASIL ALFABETIZADO, (2010) Disponível em

http://artigos.netsaber.com.br/resumo artigo 44274/artigo sobre evasao-de-educaao-dejovens-e-adultos-no-programa-brasil-alfabetizado. Acesso em 25/07/14.

DI PIERRO, Maria Clara; JOIA, Orlando; RIBEIRO, Vera Masagão. Visões da educação de jovens e adultos no Brasil. Cad. CEDES, Campinas, v. 21, n. 55, Nov. 2001 Disponível em: http://www.scielo.br/scielo.php?script=sci_arttext\&pid=S0101$32622001000300005 \& l a n g=p t$ >. Acesso em 09 jul. 2014.

DUARTE, Zalina Maria. EDUCAÇÃO A DISTÂNCIA (EAD): ESTUDO DOS FATORES CRÍTICOS DE SUCESSO NAGESTÃO DE CURSOS DA REGIÃO METROPOLITANA DE BELO HORIZONTE. 2011. Dissertação (Mestrado em Administração de Empresas) - Curso de Administração de Empresas da Universidade 
FUMEC, Belo Horizonte, 2011 Disponível em http://www.fumec.br/anexos/cursos/mestrado/dissertacoes/completa/zalina maria.pdf. Acesso em 23 jun. 2014.

ENS, Romilda Teodora; RIBAS Marciele Stiegler. POLÍTICAS EDUCACIONAIS E O ACESSO E PERMANÊNCIA NA EDUCAÇÃO DE JOVENS E ADULTOS (2012). Disponível em

http://www.ucs.br/etc/conferencias/index.php/anpedsul/9anpedsul/paper/viewFile/1685 1709. Acesso em 28/07/14.

FARIA, Maria de Oliveira Lílian; PINTO, Gisele de Magalhães. EVASÃO NA MODALIDADE A DISTÂNCIA EM CURSOS DE GRADUAÇÃO. Ciência Atual | Rio de Janeiro | Volume 4, No 2 • 2014 | inseer.ibict.br/cafsj | Pg. 02-09

FAVRETTO, Rosani Aparecida Dias; CORDOVA, Tania. A IMPLANTAÇÃO DA EAD NA MODALIDADE DE EDUCAÇÃO DE JOVENS E ADULTOS: O MODELO DO SESI EM SANTA CATARINA. Florianópolis - SC. 2012. Disponível em <http://www.abed.org.br/congresso2012/anais/10x.pdf>. Acesso em 01 mai. 2014

GAUDÊNCIO, Sale Gaudêncio. Pesquisa social: teoria, método e criatividade. 29. ed. Petrópolis, RJ: Vozes, 2010. (Coleção temas sociais). Disponível em: http://mariogaudencio.wordpress.com/2013/01/02/maria-cecilia-de-souzaminayol. Acessado em 03 de out. 2014.

MACHADO, Fernanda Quixabeira et al. O ensino médio a distância: uma experiência com os trabalhadores da indústria de Mato Grosso. Disponível em: http://www.abed.org.br/congresso2011/cd/146.pdf. Acesso em: 30 jul. 2014.

MARCONI, Marina de Andrade; LAKATOS, Eva Maria. Fundamentos de metodologia científica. 7. Ed. São Paulo: Atlas, 2010. 
MUNOZ, Manuel Alfonso Dias. PEREIRA, Denílson Diniz. LIMA, Sandra Gorete Calixto Alves Cia. Ensino a Distância: Uma proposta pedagógica emergente para a Educação de Jovens e Adultos na educação básica. Formação@docente, v. 2, n. 1, 2010. Disponível em:

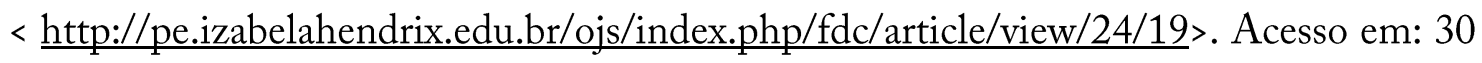
jul. 2014.

PACHECO, Hasla de Paula; MARINHO, Ramuth Pereira. Aproximação possível: Implicações da articulação da EJA e a EAD. Disponível em: <http://www.esocite.org.br/eventos/tecsoc2011/cd-anais/arquivos/pdfs/artigos/gt008aproximacaopossivel.pdf>. Acesso em 30 jul. 2014.

SALDANHA, Claudia Fernanda Assis. Atores, Tempos e Processos de Democratização nas Políticas Públicas de Educação no Município de São Gonçalo - RJ (2001-2004) (2006). Disponível em <.www.uff.br/pos_educacao/joomla/images/stories/.../saldanhad2006.pdf. Acessado em 21/10/14..

SILVA, A. C. R. Educação a Distância e o seu grande desafio: o aluno como sujeito de sua própria aprendizagem. Abed, 2004. Disponível em: <http://www.abed.org.br/congresso2004/por/htm/012-tc-a2.htm> .Acesso em 24 de Agosto de 2014.

SILVA, Alessandra Maria Inácio Dantas da, Silva, Cleonice Duarte da. A autoestima como mediação: uma proposta para diminuir a interrupção do processo formativo escolar dos estudantes da Educação de Jovens e Adultos - EJA. Disponível em: http://hdl.handle.net/10483/7756. Acesso 30 de Julho de 2014.

SILVA, Aline Daniele Bueno da. A EJA na modalidade a distância: facilidades e implicações. 2009, 26 f. Trabalho de conclusão (Especialização) - Universidade Federal do Rio Grande do Sul. Bento Gonçalves, 2009. Disponível em: http://bento.ifrs.edu.br/site/midias/arquivos/201051103752984aline daniele bueno da silva.pdf. Acesso em: 09 jul. 2014. 
SILVA, Josiel Pereira da. Educação de Jovens e Adultos: Desafios e possibilidades.Disponível em: http://dspace.bc.uepb.edu.br:8080/xmlui/handle/123456789/4451 acesso: 30 de Julho de 2014.

SOARES, Suely Galli. Educação e comunicação: O ideal de inclusão pelas tecnologias de informação: Otimismo exacerbado e lucidez pedagógica. São Paulo: Editora Cortez, 2006

VILHENA, Edna Regina Andrade. A educação de jovens e adultos na modalidade a distância: o impacto da gestão no combate a evasão. 2012, 156f. Dissertação (Mestrado em Educação) - Universidade Católica de Brasília, Brasília, 2012. Disponível em: http://www.bdtd.ucb.br/tede/tde busca/arquivo.php?codArquivo=1776. Acesso em: 09 jul. 2014. 